\title{
Premenopausal Trabecular Bone Loss is Associated with a Family History of Fragility Fracture
}

\author{
Prämenopausaler trabekulärer Knochendichteverlust ist mit einer \\ Familienanamnese für niedrig-traumatische Frakturen assoziiert
}

Authors

Affiliations
J. C. Prior ${ }^{1,2,3}$, C. L. Hitchcock ${ }^{1}$, Y. M. Vigna ${ }^{1}$, V. Seifert-Klauss ${ }^{4}$

The affiliations are listed at the end of the article.
Key words
osteoporosis
QCT
bone turnover
menstrual cycle
estrogen
genetics

Schlüsselwörter

- Osteoporose

- QCT

- Knochenumsatz

- Menstruationszyklus

- Östrogen

- Genetik $\begin{array}{lr}\text { received } & 9.12 .2015 \\ \text { revised } & 19.2 .2016 \\ \text { accepted } & 23.2 .2016\end{array}$

Bibliography

Dol http://dx.doi.org/

10.1055/s-0042-103751

Published online

Geburtsh Frauenheilk 2016; 76:

895-901 ๔ Georg Thieme

Verlag KG Stuttgart · New York

ISSN 0016-5751

Correspondence

V. Seifert-Klauss, MD, PhD

Frauenklinik und Poliklinik

der Technischen Universität

München (TUM)

Ismaninger Straße 22

81675 München

vanadin.seifert-klauss@tum.de

http://www.frauenklinik.

med.tum.de/node/336

\section{Abstract \\ $\nabla$}

Introduction: Although a fragility fracture family history ( $\mathrm{FFFH}+$ ) has repeatedly been shown to be associated with lower bone mineral density (BMD), its relationship to human BMD change is unclear. Animal research, however, documented that different purebred strains within rodent species have wide ranges in rates of bone acquisition during growth as well as in change post-ovariectomy. Our objective was to compare the rate of premenopausal spinal trabecular BMD change between women with and without a general family history of fragility fracture.

Participants and Methods: Healthy premenopausal community women participated in prospective observational studies at two academic medical research centres: Vancouver, Canada $(n=66)$ and Munich, Germany $(n=20)$. The primary outcome was annual spinal BMD change, measured by quantitative computed tomography (QCT). The two studies employed similar methodologies for assessing QCT and FFFH.

Results: Volunteer community participants had a mean age of 36.0 (SD, 6.9) years, body mass index 22.5 (2.4) and baseline QCT of 150.2 (22.5) $\mathrm{mg} /$ $\mathrm{cm}^{3}$ trabecular bone. The rates of BMD change were similar in both cities: -3.5 (5.1)/year Vancouver, -2.0 (3.4)/year Munich (95\% CI of difference: $-3.9,0.9$ ). Over a third of the women (31 of the $86,36 \%$ ) reported FFFH+. Those with and without a FFFH were similar in demographics, nutrition, exercise, menstrual cycle and luteal phase lengths and physiological measures (serum calcium, osteocalcin and estradiol). However, women with FFFH+ lost trabecular BMD more rapidly: FFFH+, - 4.9 (5.0), FFFH-, - 2.2 (4.4) $\mathrm{mg} / \mathrm{cm}^{3} /$ year (95\% CI diff -0.7 to $-4.8, \mathrm{~F}_{1.83}=7.88, \mathrm{p}=0.006$ ). $\mathrm{FFFH}+$ explained $7.7 \%$ of the variance in QCT volumetric trabecular spinal bone change/year in these healthy premenopausal women.

\section{Zusammenfassung \\ $\nabla$}

Einleitung: Obwohl Studien einen Zusammenhang zwischen einer Familienanamnese von Fragilitätsfrakturen (FFFH+) und geringerer Knochenmineraldichte aufgezeigt haben, ist es nicht klar, wie dies mit Veränderungen der menschlichen Knochendichte zusammenhängt. Tierstudien haben aber gezeigt, dass die Zuwachsraten für die Bildung neuer Knochenmasse sowohl im Wachstumsalter wie auch nach der Ovariektomie bei unterschiedlichen Unterarten einer reinrassigen Nagetierart sehr unterschiedlich ausfallen können. Ziel dieser Studie war es, Veränderungen der trabekulären Knochenmineraldichte der Wirbelsäule in prämenopausalen Frauen mit und ohne Familienvorgeschichte von Fragilitätsfrakturen zu vergleichen.

Teilnehmer und Methoden: Gesunde prämenopausale Frauen nahmen an 2 prospektiven Beobachtungsstudien teil, die von 2 medizinischen Forschungszentren (Vancouver, Kanada [ $n=66$ ] bzw. München, Deutschland $[n=20]$ ) durchgeführt wurden. Das Primärergebnis war die Feststellung der jährlichen Veränderungen der Wirbelsäulen-Knochendichte. Die Knochendichte wurde mithilfe der quantitativen Computertomografie (QCT) gemessen. Beide Studien verwendeten eine ähnliche Methodologie zur Beurteilung von QCT und FFFH.

Ergebnisse: Das Durchschnittsalter der freiwilligen Teilnehmerinnen betrug 36,0 (SD 6,9) Jahre, der durchschnittliche Körpermasseindex war 22,5 $(2,4)$ und der durchschnittlich gemessene Ausgangswert (QCT-Messung) der trabekulären Knochendichte betrug 150,2 (22,5) mg/ $\mathrm{cm}^{3}$. Die Knochendichte-Veränderungsraten waren in beiden Städten ähnlich: $-3,5(5,1) / J a h r$ Vancouver, -2,0 (3,4)/Jahr München (95\%-KI für die Differenz der Mittelwerte: $-3,9 ; 0,9)$. Mehr als ein Drittel aller Frauen in den 2 Studien (31 aus 86, 36\%) berichteten von Fragilitätsfrakturen in ihren Famili- 
Conclusion: This study shows for the first time that having a history of a fragility fracture in a family member is associated with a greater rate of premenopausal spinal trabecular bone loss. en (FFFH+). Zwischen den Frauen mit und ohne FFFH gab es keine signifikanten Unterschiede bez. ihrer demografischen Daten, Ernährung, sportlichen Aktivität, Menstruationszyklus und Dauer der Lutealphase und auch keine signifikanten Unterschiede in den physiologischen Werten (Serumkalzium, Osteocalcin und Estradiol). Es stellte sich aber heraus, dass die Abnahme trabekulärer Knochendichte bei Frauen mit FFFH+ viel schneller erfolgte: FFFH+ $-4,9(5,0)$; FFFH- $-2,2(4,4) \mathrm{mg} / \mathrm{cm}^{3} / \mathrm{Jahr}\left(95 \%-\mathrm{KI}_{\text {diff }}-0,7\right.$ bis $\left.-4,8 ; F_{1,83}=7,88 ; \mathrm{p}=0,006\right)$. FFFH+ erklärte 7,7\% der Abweichung in den mit QCT gemessenen volumetrischen trabekulären Veränderungen der Wirbelsäulen-Knochendichte/Jahr in diesen gesunden prämenopausalen Frauen.

Schlussfolgerung: Die Studien zeigten damit zum ersten Mal, dass in prämenopausalen Frauen eine Familienanamnese von Fragilitätsfrakturen mit einer höheren Rate an trabekulärem Knochendichteverlust der Wirbelsäule assoziiert ist.

\section{Introduction}

$\nabla$

The identification of clinical risk factors for fragility fracture provides the potential for prevention of osteoporosis. One risk factor to predict hereditary risk of osteoporosis is a biological relative who has experienced a low-trauma fracture - this is considered a fragility fracture family history (FFFH+) [1]. The increased fracture risk conferred by a parent with a hip fracture is modest (RR about 1.5), but it was independent of bone mineral density (BMD) in a meta-analysis of population-based prospective studies [1]. BMD and the presence of fragility fractures have long been known to relate to genetic as well as to environmental factors [2, $3]$. In the era of densitometry, osteoporosis is commonly defined by a low T-score [4] or by a high estimated 10-year risk of fragility fracture as predicted by sex, age and other clinical risk factors with or without BMD $[5,6]$, rather than, as commonly in the past, by a history of having personally experienced a low trauma fracture [7].

Most research on the genetics of osteoporosis has been cross-sectional in nature, whether using monozygous and dyzygous twins $[8,9]$ or performing genome-wide association studies (GWAS) [10-12]. In addition, until recently the genetics of BMD in older men and women (at higher fracture risk) rather than in younger women and men (where genetics may play a larger role) has been the focus of most GWAS and meta-analyses of genomewide associations [12]. However, several animal studies clearly show that rates of change in bone growth and strength [13] as well as in acute post-oophorectomy bone change [14] differ by highly inbred genetic strain within rodent species. Twin studies also show a small portion of BMD heritability is related to bone turnover markers [15].

By contrast, an association between longitudinal change in BMD and a family history of fragility fracture has proved more elusive. Although bone remodelling rate is associated with both BMD and fracture $[16,17]$, the few prospective human studies that have assessed change in BMD in twins have been unable to show associations. For example, radial bone change over 16-years in twin men was unrelated to heredity [18]. Also, four-year change in lumbar spine BMD in women twins could show heritability only by using a 1-tailed T-test [19]. Likewise, population-based prospective studies in younger women, the majority of whom were either premenopausal [20] or perimenopausal [21], have been unable to show areal BMD change rate differences (by dual en- ergy X-ray [DXA] measurements) related to the presence or absence of FFFH.

Thus, although it is logical that an increased rate of BMD loss would be found in those with a history of a family member who suffered a fragility fracture, this has not yet been documented to date. The ability to detect differences in bone change is related to sample size, duration of study, the sex of the sample, their position within the lifecycle and to the type of bone that is being assessed. In particular, cortical bone changes more slowly than trabecular bone; previous studies have assessed peripheral cortical bone (radius) or areal BMD (by DXA) that includes both cortical and trabecular bone compartments. These measures are less sensitive to change than volumetric trabecular bone measured by quantitative computed tomography (QCT). Therefore the purpose of this pooled analysis was to assess rates of BMD change in healthy menstruating women who did or did not have a relative with a low trauma fracture by examining change in spinal volumetric trabecular BMD by QCT.

\section{Materials and Methods \\ $\nabla$}

Regularly menstruating, primarily white women from prospective, observational BMD studies in two centers (Vancouver, Canada and Munich, Germany) were included. Both cohorts included only volunteer community participants in whom bone-relevant or endocrine disease had been excluded as reported in the original publications $[22,25,26]$. All 20 in the Munich cohort and 64 of 66 in the Vancouver cohort were Caucasian. Quantitative Computer Tomography (QCT) was used for measuring spinal volumetric trabecular bone. Within both cohorts, FFFH was assessed by questionnaire: "Has a biological relative broken a bone without major trauma or developed height loss and become hunched?" Both studies were approved by local university ethics boards (Clinical Research Ethics Board, University of British Columbia; Ethikkommission der Medizinischen Fakultät TUM) and followed the principles of Helsinki. All women provided written informed consent.

\section{Vancouver cohort}

As previously reported, in 1985-1987 premenopausal women were recruited to a one-year study of QCT bone change by exercise and menstrual cycle characteristics [22]. The 66 women were ages 20 to 42, healthy, non-smoking, of normal weight and 
not taking hormones. According to complete dietary data they had healthy diets and none were deficient in nutrients nor excessively supplementing. All reported regular menstrual cycles and prior to study entry were required to have two consecutive, normal length (21-36 day) cycles with normal ovulation (luteal phase lengths of $\geq 10$ days) as assessed by the validated quantitative basal temperature method [23,24]. Women varied in exercise habits from normally active to training for and running a marathon during the study. Menstrual cycle and ovulatory characteristics were similar across exercise habits and menstruation remained regular throughout the one-year study with no one developing oligomenorrhea or amenorrhea. The family history of a fragility fracture was updated five years after baseline [25].

\section{Munich cohort}

Caucasian community women volunteers over age 30 were recruited to a prospective study of midlife bone change [26]. Only those 20 of these who were initially and remained premenopausal at the two-year QCT measurement were included in the present analysis. They were healthy, normally active, not taking hormones, nor high-dose nutrition supplements or bone relevant medications and a response about FFFH was obtained at baseline in 2001-2 [26]. The questionnaire data on whether or not a relative had experienced a fragility fracture were reviewed and answers updated with participants in December 2010.

\section{Bone measurement - volumetric trabecular} spinal bone mineral density by QCT

In Vancouver, QCT of thoracic 12th through lumbar 3rd vertebrae was measured in duplicate with repositioning at baseline and at 12 months by computed tomography (Siemens DR2, $96 \mathrm{kV}$, $300 \mathrm{mAs}$; slice thickness $8 \mathrm{~mm}$ ), using an edge detection method with within-person reproducibility with repositioning of 0.8 [22]. These data were converted into mineral equivalents of dibasic potassium phosphate and reported as $\mathrm{mg} / \mathrm{cm}^{3}$ using a phantom developed by Genant and Cann [28].

In Munich, QCT of lumbar vertebrae 1 through 3 was measured at baseline and two-years. The center of each vertebra was located using a scout film [26]. The computed tomography instruments (two of identical make were utilized; Somatom by Siemens, Erlangen, Germany; $80 \mathrm{kVp}$ at $146 \mathrm{mAs}$ ) gave results that were calibrated, reported as $\mathrm{mg} / \mathrm{cm}^{3}$ and standardized using measurements of the hydroxyapatite-containing European Spine Phantom [29]. This phantom shows parallel age-related cross-sectional data with the original QCT Genant and Cann phantom [28]. All QCT change data were annualized before analysis.

Demographic, reproductive, educational and medical histories were obtained by questionnaire. All women in Vancouver had their height measured in stocking feet and weight measured on a balance beam in light clothing. In Munich, women reported their most recently recalled height and weight. In Vancouver, Menstrual Cycle Diary records for the entire year were used to compute average menstrual cycle length and average luteal phase length was derived by quantitative basal temperature analysis $[23,24]$. The Munich cohort was asked to recall their minimum and maximum menstrual cycle lengths at 6-monthly intervals ( 5 times over two years); mean menstrual cycle length was computed from the average of all these values.

Serum and urine specimens were collected in both studies. In the Vancouver cohort serum and fasting urine were obtained in both the mid-follicular and the premenstrual phases of the initial and final cycles of the study year. Methods for all biochemical and hormonal measurements are as previously reported [22,32]. In the Munich cohort, fasting serum and urine samples were obtained at baseline, as well as at three, six, nine, 12 and 24 month visits and without cycle timing. Methods for all these hormonal and biochemical variables are as previously reported [27,32]. For each variable, a within-woman average was computed and used in this analysis.

\section{Statistical analysis}

The primary outcome was annualized QCT change [30]. Within each cohort, characteristics of women with and without a family fragility fracture history were compared using T-tests, cross-tabulation or non-parametric tests, as appropriate. Luteal phase length, a variable that has been previously found to account for $20 \%$ of variability in QCT change [22], was only available for the Vancouver cohort. Accordingly, tertile of mean luteal phase length (luteal tertile) was included as a covariate for analysis of the Vancouver FFFH data; thus annual QCT change was analyzed by two-factor Analysis of Variance (ANOVA) by luteal phase length tertile and FFFH status. For combined cohorts, annual QCT change was analyzed by two-factor ANOVA by center and FFFH. Data are reported as the mean, median and standard deviation (SD). Differences by whether or not women had FFFH+ are reported as mean and $95 \%$ confidence intervals $(\mathrm{CI})$ of the difference. All tests were two-tailed with $\mathrm{p}=0.05$ accepted as statistically significant.

\section{Results}

Data are presented first for each cohort separately, their differences and then the combined cohort that provided the important, primary results.

\section{Vancouver cohort}

Within the Vancouver cohort 22 of the 66 women (33\%) gave a positive history of a family fragility fracture (FFFH+) ( $\bullet$ Table 1 ). This cohort averaged 33.7 years of age at baseline with a body mass index (BMI) of 22.1 and an initial QCT of $154.3 \mathrm{mg} / \mathrm{cm}^{3}$ [22]. The presence or absence of FFFH was not associated with differences in age, weight, height, BMI, exercise or the mean of four 7-day diet diary characteristics (not reported) or with oneyear changes in these variables ( Table 1). Cycle lengths, however, averaged 29.2 in those with a FFFH+ versus 28 days in women without ( $p=0.06$ ). Between those with/without FFFH there were no significant differences in luteal phase lengths or exercise patterns $-61 \%$ of FFFH- and $73 \%$ of FFFH+ women used running as their primary form of physical activity (Fisher's exact test $\mathrm{p}=0.42$ ). Women with and without FFFH also did not differ in average serum levels of estradiol, progesterone, calcium, or osteocalcin but women who were FFFH+ had significantly lower total alkaline phosphatase levels ( $\bullet$ Table 1 ). Although both baseline and one-year cross-sectional QCT values were similar by $\mathrm{FFFH} \pm$, those with a family history of fragility fracture (FFFH+) showed a greater annual QCT rate of BMD loss than those without ( Table 1).

- Fig. 1 shows the one-year change in QCT in the Vancouver cohort with and without a FFFH represented in tertiles of luteal phase length (Tertile 1: 4.6-10.1; Tertile 2: 10.2-11.3; Tertile 3: 11.4-13.7 days) since luteal phase length explained $20 \%$ of the variance in QCT change [22]. By 2-factor ANOVA, QCT change/ year was significantly related to luteal phase length $\left(F_{2,59}=5.51\right.$, 
Table 1 Munich cohort and Vancouver cohort: baseline and final demographic and quantitative computed tomography of volumetric trabecular spinal bone $\left(\mathrm{QCT}, \mathrm{mg} / \mathrm{cm}^{3}\right.$ ) and QCT changes for the 20 Munich and 66 Vancouver women, by fragility fracture family history (FFFH \pm ). The $95 \%$ confidence interval (Cl) of the difference and p-values are shown in the final two columns with significant differences in bold. Note: Munich: 2-year QCT interval, Vancouver: 1-year QCT interval.

\begin{tabular}{|c|c|c|c|c|c|c|c|c|}
\hline & Munich & & & & Vancouv & ohort & & \\
\hline & $\begin{array}{l}\text { FFFH- } \\
(n=11)\end{array}$ & $\begin{array}{l}\text { FFFH+ } \\
(n=9)\end{array}$ & $\begin{array}{l}\text { Difference } \\
\text { (95\% Cl) }\end{array}$ & $\mathbf{p}$ & $\begin{array}{l}\text { FFFH- } \\
(n=44)\end{array}$ & $\begin{array}{l}\text { FFFH }+ \\
(n=22)\end{array}$ & $\begin{array}{l}\text { Difference } \\
(95 \% \mathrm{Cl})\end{array}$ & $\mathbf{p}$ \\
\hline Age $(y)$ & $\begin{array}{l}43.6 \\
(4.5)\end{array}$ & $\begin{array}{l}43.2 \\
(6.5)\end{array}$ & $\begin{array}{l}0.4 \\
(-4.8 \text { to } 5.6)\end{array}$ & 0.87 & $\begin{array}{l}33.5 \\
(5.8)\end{array}$ & $\begin{array}{l}34.3 \\
(5.2)\end{array}$ & $\begin{array}{l}-0.9 \\
(-3.8 \text { to } 2.1)\end{array}$ & 0.56 \\
\hline Height $(\mathrm{cm})$ & $\begin{array}{l}165.9 \\
(6.4)\end{array}$ & $\begin{array}{l}164.3 \\
(8.9)\end{array}$ & $\begin{array}{l}1.6 \\
(-5.6 \text { to } 8.7)\end{array}$ & 0.65 & $\begin{array}{l}161.3 \\
(6)\end{array}$ & $\begin{array}{l}163.5 \\
(7.1)\end{array}$ & $\begin{array}{l}-2.2 \\
(-5.5 \text { to } 1.1)\end{array}$ & 0.19 \\
\hline Baseline weight $(\mathrm{kg})$ & $\begin{array}{l}67.2 \\
(13.2)\end{array}$ & $\begin{array}{l}62.1 \\
(10.7)\end{array}$ & $\begin{array}{l}5.2 \\
\text { (-6.9 to } 17.2)\end{array}$ & 0.38 & $\begin{array}{l}58.1 \\
(5.3)\end{array}$ & $\begin{array}{l}58.3 \\
(8.7)\end{array}$ & $\begin{array}{l}-0.2 \\
(-3.6 \text { to } 3.2)\end{array}$ & 0.92 \\
\hline Change in weight $(\mathrm{kg})$ & $\begin{array}{l}0.2 \\
(4.1)\end{array}$ & $\begin{array}{l}-0.6 \\
(2.2)\end{array}$ & $\begin{array}{l}0.7 \\
(-3.2 \text { to } 4.6)\end{array}$ & 0.69 & $\begin{array}{l}0.5 \\
(2.9)\end{array}$ & $\begin{array}{l}-0.6 \\
(2.9)\end{array}$ & $\begin{array}{l}1.1 \\
(-0.4 \text { to } 2.7)\end{array}$ & 0.14 \\
\hline Baseline BMI & $\begin{array}{l}24.3 \\
(3.7)\end{array}$ & $\begin{array}{l}23.2 \\
(3)\end{array}$ & $\begin{array}{l}1.1 \\
\text { (-2.1 to } 4.3)\end{array}$ & 0.49 & $\begin{array}{l}22.4 \\
(1.7)\end{array}$ & $\begin{array}{l}21.7 \\
(2.4)\end{array}$ & $\begin{array}{l}0.7 \\
(-0.3 \text { to } 1.7)\end{array}$ & 0.18 \\
\hline Change in BMI & $\begin{array}{l}0.3 \\
(1.4)\end{array}$ & $\begin{array}{l}-0.2 \\
(0.8)\end{array}$ & $\begin{array}{l}0.5 \\
(-0.9 \text { to } 1.8)\end{array}$ & 0.47 & $\begin{array}{l}0.1 \\
(1)\end{array}$ & $\begin{array}{l}-0.2 \\
(1.2)\end{array}$ & $\begin{array}{l}0.3 \\
(-0.3 \text { to } 0.8)\end{array}$ & 0.33 \\
\hline Baseline QCT $\left(\mathrm{mg} / \mathrm{cm}^{3}\right)$ & $\begin{array}{l}142.9 \\
(18.6)\end{array}$ & $\begin{array}{l}139.9 \\
(25.3)\end{array}$ & $\begin{array}{l}3.0 \\
(-17.6 \text { to } 23.6)\end{array}$ & 0.76 & $\begin{array}{l}155.4 \\
(21.8)\end{array}$ & $\begin{array}{l}152.1 \\
(22.0)\end{array}$ & $\begin{array}{l}3.3 \\
(-8.1 \text { to } 14.7)\end{array}$ & 0.57 \\
\hline Final QCT $\left(\mathrm{mg} / \mathrm{cm}^{3}\right)$ & $\begin{array}{l}139.7 \\
(18.2)\end{array}$ & $\begin{array}{l}134.9 \\
(23.6)\end{array}$ & $\begin{array}{l}4.7 \\
(-14.9 \text { to } 24.3)\end{array}$ & 0.62 & $\begin{array}{l}153.3 \\
(22.1)\end{array}$ & $\begin{array}{l}146.7 \\
(21.7)\end{array}$ & $\begin{array}{l}6.6 \\
(-4.9 \text { to } 18.0)\end{array}$ & 0.25 \\
\hline $\mathrm{QCT}$ change $/ \mathrm{y}\left(\mathrm{mg} / \mathrm{cm}^{3}\right)$ & $\begin{array}{l}-1.6 \\
(3.5)\end{array}$ & $\begin{array}{l}-2.5 \\
(3.3)\end{array}$ & $\begin{array}{l}0.8 \\
(-2.4 \text { to } 4.1)\end{array}$ & 0.60 & $\begin{array}{l}-2.3 \\
(4.7)\end{array}$ & $\begin{array}{l}-5.9 \\
(5.2)\end{array}$ & $\begin{array}{l}3.6 \\
\text { (1.1 to } 6.2)\end{array}$ & 0.006 \\
\hline Menstrual cycle length (days) & $\begin{array}{l}28.0 \\
(3.6)\end{array}$ & $\begin{array}{l}30.3 \\
(4.1)\end{array}$ & $\begin{array}{l}-2.3 \\
(-6.4 \text { to } 1.9)\end{array}$ & 0.26 & $\begin{array}{l}28.0 \\
(2.1)\end{array}$ & $\begin{array}{l}29.2 \\
(2.8)\end{array}$ & $\begin{array}{l}-1.2 \\
(-2.4 \text { to } 0.0)\end{array}$ & 0.06 \\
\hline Serum calcium (mmol/L) & $\begin{array}{l}2.33 \\
(0.05)\end{array}$ & $\begin{array}{l}2.30 \\
(0.06)\end{array}$ & $\begin{array}{l}0.03 \\
(-0.02 \text { to } 0.09)\end{array}$ & 0.19 & $\begin{array}{l}2.3 \\
(0.1)\end{array}$ & $\begin{array}{l}2.3 \\
(0.1)\end{array}$ & $\begin{array}{l}-0.1 \\
(-0.1 \text { to } 0.0)\end{array}$ & 0.09 \\
\hline Serum phosphate (mmol/L) & $\begin{array}{l}1.09 \\
(0.09)\end{array}$ & $\begin{array}{l}1.12 \\
(0.12)\end{array}$ & $\begin{array}{l}-0.04 \\
(-0.14 \text { to } 0.07)\end{array}$ & 0.46 & $\begin{array}{l}1.2 \\
(0.1)\end{array}$ & $\begin{array}{l}1.1 \\
(0.1)\end{array}$ & $\begin{array}{l}0.03 \\
(-0.2 \text { to } 0.8)\end{array}$ & 0.29 \\
\hline Alkaline phosphatase (IU/L) & & & & & $\begin{array}{l}54.6 \\
(15.4)\end{array}$ & $\begin{array}{l}46.6 \\
(11.0)\end{array}$ & $\begin{array}{l}-8.0 \\
(-0.6 \text { to }-15.4)\end{array}$ & 0.03 \\
\hline Pyridinoline ( $\mathrm{nmol} / \mathrm{mmol} \mathrm{Cr}$ ) & $\begin{array}{l}34.26 \\
(5.52)\end{array}$ & $\begin{array}{l}35.29 \\
(7.61)\end{array}$ & $\begin{array}{l}-1.03 \\
(-7.20 \text { to } 5.14)\end{array}$ & 0.73 & & & & \\
\hline Deoxypyridinoline $(\mathrm{nmol} / \mathrm{mmol} \mathrm{Cr}$ ) & $\begin{array}{l}7.72 \\
(1.64)\end{array}$ & $\begin{array}{l}8.02 \\
(1.57)\end{array}$ & $\begin{array}{l}-0.30 \\
(-1.82 \text { to } 1.22)\end{array}$ & 0.68 & & & & \\
\hline Vitamin D (ng/ml) & $\begin{array}{l}24.01 \\
(8.54)\end{array}$ & $\begin{array}{l}24.08 \\
(8.48)\end{array}$ & $\begin{array}{l}-0.07 \\
\text { (-8.11 to } 7.97)\end{array}$ & 0.99 & & & & \\
\hline Percent runners & & & & & $\begin{array}{l}27 \\
(61.4 \%)\end{array}$ & $\begin{array}{l}16 \\
(72.7 \%)\end{array}$ & & $0.42^{\#}$ \\
\hline Osteocalcin (ng/ml) & $\begin{array}{l}4.82 \\
(0.80)\end{array}$ & $\begin{array}{l}5.49 \\
(1.06)\end{array}$ & $\begin{array}{l}-0.68 \\
(-1.54 \text { to } 0.19)\end{array}$ & 0.12 & $\begin{array}{l}4.0 \\
(1.2)\end{array}$ & $\begin{array}{l}4.0 \\
(1.0)\end{array}$ & $\begin{array}{l}0.1 \\
(-0.5 \text { to } 0.7)\end{array}$ & 0.86 \\
\hline $\begin{array}{l}\text { Bone-specific alkaline phosphatase } \\
(\mathrm{ng} / \mathrm{ml})\end{array}$ & $\begin{array}{l}7.62 \\
(2.03)\end{array}$ & $\begin{array}{l}8.48 \\
(2.27)\end{array}$ & $\begin{array}{l}-0.85 \\
(-2.87 \text { to } 1.17)\end{array}$ & 0.39 & & & & \\
\hline N-Telopeptide (nmol BCE/mmol Cr) & $\begin{array}{l}32.22 \\
(8.09)\end{array}$ & $\begin{array}{l}41.24 \\
(9.63)\end{array}$ & $\begin{array}{l}-9.02 \\
(-17.34 \text { to }-0.70)\end{array}$ & 0.04 & & & & \\
\hline C-Telopeptide (ng/ml) & $\begin{array}{l}0.16 \\
(0.07)\end{array}$ & $\begin{array}{l}0.30 \\
(0.14)\end{array}$ & $\begin{array}{l}-0.14 \\
(-0.24 \text { to }-0.04)\end{array}$ & 0.01 & & & & \\
\hline Urinary calcium ( $\mathrm{mmol} / \mathrm{mmol} \mathrm{Cr}$ ) & $\begin{array}{l}0.3 \\
(0.1)\end{array}$ & $\begin{array}{l}0.5 \\
(0.4)\end{array}$ & $\begin{array}{l}-0.2 \\
(-0.5 \text { to } 0.0)\end{array}$ & 0.08 & $\begin{array}{l}0.4 \\
(0.2)\end{array}$ & $\begin{array}{l}0.4 \\
(0.2)\end{array}$ & $\begin{array}{l}0.0 \\
(-0.7 \text { to } 0.1)\end{array}$ & 0.56 \\
\hline Estradiol (pmol/L) & $\begin{array}{l}372.9 \\
(173.3)\end{array}$ & $\begin{array}{l}354.1 \\
(211.5)\end{array}$ & $\begin{array}{l}18.8 \\
(-161.8 \text { to } 199.4)\end{array}$ & 0.83 & $\begin{array}{l}291.1 \\
(19.3)\end{array}$ & $\begin{array}{l}255.4 \\
(84.6)\end{array}$ & $\begin{array}{l}35.7 \\
(-23.9 \text { to } 95.2)\end{array}$ & 0.24 \\
\hline Progesterone (nmol/L) & & & & & $\begin{array}{l}15.5 \\
(8.1)\end{array}$ & $\begin{array}{l}12.3 \\
(6.4)\end{array}$ & $\begin{array}{l}-3.2 \\
(0.8 \text { to }-7.1)\end{array}$ & 0.12 \\
\hline
\end{tabular}

\# \% runners: Fisher's exact test

$\mathrm{p}=0.006)$ as well as to a family history of fragility fracture $\left(F_{1,59}=9.74, p=0.003\right)$. However, there was no luteal length by FFFH interaction $\left(F_{2,59}=0.7\right)$ in the Vancouver cohort.

\section{Munich cohort}

In the Munich cohort, nine of 20 women (45\%) gave a history of a family member with fragility fracture ( $\mathrm{FFFH}+$ ). The women in this cohort were on average 43.5 years old with a BMI of 23.8 and an initial QCT of $141.6 \mathrm{mg} / \mathrm{cm}^{3}$. O Table 1 shows that Munich women with $\mathrm{FFFH}+$ did not differ in any demographic or reproductive variable from women without this history. However, women with $\mathrm{FFFH}+$ had bone resorption markers that were higher mean N-telopeptide levels were $9.02 \mathrm{nmol} \mathrm{BCE} / \mathrm{mmol} \mathrm{Cr}(95 \%$ CI: 0.70 to 17.34) higher and C-telopeptide levels were $0.14 \mathrm{ng} /$ $\mathrm{ml}(95 \% \mathrm{CI}: 0.04$ to 0.24$)$ higher than in women without FFFH. All other mean hormonal and bone metabolism markers were not 
different ( $\bullet$ Table 1 ). The numerically greater rate of bone loss in Munich women with FFFH+ compared to those without did not reach statistical significance.

\section{Cohort comparisons and differences}

The Vancouver and Munich cohorts, although both initially including premenopausal, healthy and primarily white women, differed in age, weight, BMI, interval between QCT measurements and baseline and final QCT values ( $\bigcirc$ Table 2 B). However, the two cohorts did not differ in the proportion of each cohort with $\mathrm{FFFH}+$, mean $36 \%$ (95\% Cl of the difference: -0.4 to 0.1 ). Nor did they differ in the annual volumetric trabecular bone change by QCT (Vancouver $=-3.5$ and Munich $=-2.0 \mathrm{mg} / \mathrm{cm}^{3}$ per year; $95 \% \mathrm{CI}$ of the difference: -3.9 to, 0.9 ).

The combined cohorts as shown in $\mathbf{0}$ Table $\mathbf{2} \mathrm{A}$ did not differ by FFFH in any baseline or change demographic variables. For the biochemical data that were jointly available (serum calcium, phosphate, osteocalcin and estradiol levels) there was no interaction or main effect of FFFH.

\section{Combined cohort}

In the combined cohort, women with a biological relative having had a fragility fracture $(\mathrm{FFFH}+; \mathrm{n}=31)$ lost bone at a faster rate

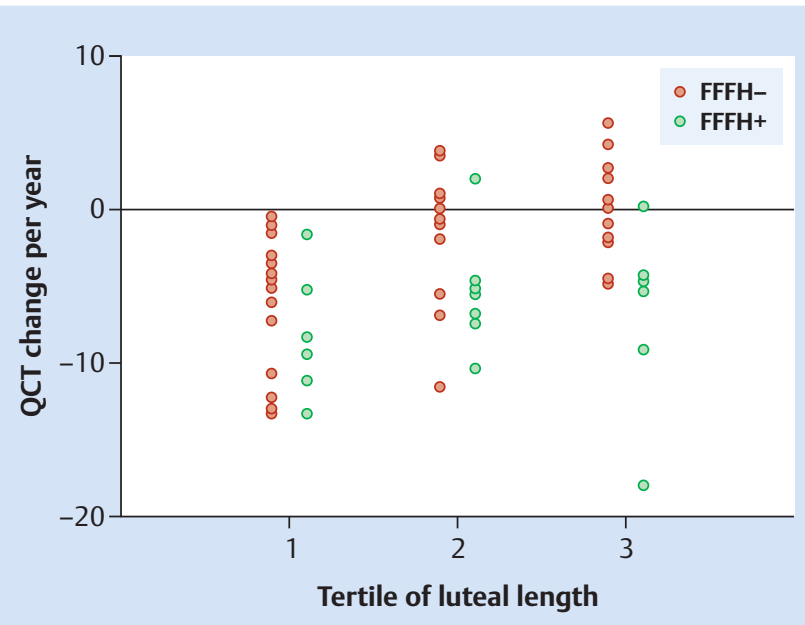

Fig. 1 Annual change in volumetric trabecular spinal bone by quantitative computed tomography (QCT) in $\mathrm{mg} / \mathrm{cm}^{3} /$ year in the 66 premenopausal, initially ovulatory women in the Vancouver Cohort, as those without a fragility fracture family history (FFFH-, $n=44)$ and those with FFFH+ $(n=22)$ by tertiles of luteal phase length (see manuscript for a further description).

Table 2 A Combined Vancouver and Munich cohorts showing the mean of the total cohort and data stratified by the absence or presence of a fragility fracture family history ( $\mathrm{FFFH} \pm$ ): baseline demographic (age, height, weight, body mass index [BMI]) and change characteristics of 86 healthy menstruating, primarily white (84 of 86) women in the combined cohorts including $36 \%$ of women with FFFH+. Cross-sectional data and longitudinal rates of change in quantitative computed tomography volumetric trabecular spinal bone mineral density $\left(\mathrm{QCT}, \mathrm{mg} / \mathrm{cm}^{3}\right)$ are shown as $95 \% \mathrm{Cl}$ of the difference with significant differences in bold.

B Comparison between the Vancouver and Munich cohorts: baseline demographics (age, height, weight, body mass index [BMI]) and change characteristics of the premenopausal women in both cohorts having quantitative computed tomography volumetric trabecular spinal bone density $\left(\mathrm{QCT}, \mathrm{mg} / \mathrm{cm}^{3}\right)$ and QCT change data: 66 women in the Vancouver cohort, studied over one year; 20 women in the Munich cohort, studied over two years. Values are mean (SD). The 95\% confidence interval $(\mathrm{Cl})$ of the difference is shown with significant differences in bold.

\begin{tabular}{|c|c|c|c|c|c|c|c|c|}
\hline & \multicolumn{4}{|c|}{ A Combined cohorts } & \multicolumn{4}{|c|}{ B Comparison between Vancouver and Munich cohort } \\
\hline & $\begin{array}{l}\text { FFFH- } \\
(n=55)\end{array}$ & $\begin{array}{l}\text { FFFH+ } \\
(n=31)\end{array}$ & $\begin{array}{l}\text { Difference } \\
(95 \% \mathrm{Cl})\end{array}$ & $\mathbf{p}$ & $\begin{array}{l}\text { Vancouver } \\
(n=66)\end{array}$ & $\begin{array}{l}\text { Munich } \\
(n=20)\end{array}$ & $\begin{array}{l}\text { Difference } \\
(95 \% \mathrm{Cl})\end{array}$ & $\mathbf{p}$ \\
\hline Age (y) & $\begin{array}{l}35.5 \\
(6.9)\end{array}$ & $\begin{array}{l}36.9 \\
(6.8)\end{array}$ & $\begin{array}{l}-1.4 \\
(-4.5 \text { to } 1.7)\end{array}$ & 0.36 & $\begin{array}{l}33.7 \\
(5.6)\end{array}$ & $\begin{array}{l}43.5 \\
(5.4)\end{array}$ & $\begin{array}{l}-9.7 \\
(-12.5 \text { to }-6.9)\end{array}$ & $<0.001$ \\
\hline Height $(\mathrm{cm})$ & $\begin{array}{l}162.2 \\
(6.3)\end{array}$ & $\begin{array}{l}163.7 \\
(7.5)\end{array}$ & $\begin{array}{l}-1.5 \\
(-4.5 \text { to } 1.5)\end{array}$ & 0.32 & $\begin{array}{l}162 \\
(6.4)\end{array}$ & $\begin{array}{l}165.2 \\
(7.4)\end{array}$ & $\begin{array}{l}-3.2 \\
(-6.6 \text { to } 0.2)\end{array}$ & 0.06 \\
\hline Baseline weight $(\mathrm{kg})$ & $\begin{array}{l}59.9 \\
(8.2)\end{array}$ & $\begin{array}{l}59.3 \\
(9.2)\end{array}$ & $\begin{array}{l}0.6 \\
(-3.2 \text { to } 4.5)\end{array}$ & 0.74 & $\begin{array}{l}58.2 \\
(6.5)\end{array}$ & $\begin{array}{l}65.1 \\
(12.2)\end{array}$ & $\begin{array}{l}-6.9 \\
(-11.1 \text { to }-2.7)\end{array}$ & 0.002 \\
\hline Change in weight $(\mathrm{kg})$ & $\begin{array}{l}0.5 \\
(3.1)\end{array}$ & $\begin{array}{l}-0.6 \\
(2.7)\end{array}$ & $\begin{array}{l}1.1 \\
(-0.3 \text { to } 2.5)\end{array}$ & 0.13 & $\begin{array}{l}0.2 \\
(2.9)\end{array}$ & $\begin{array}{l}-0.1 \\
(3.4)\end{array}$ & $\begin{array}{l}0.3 \\
(-1.4 \text { to } 2.0)\end{array}$ & 0.73 \\
\hline Baseline BMI & $\begin{array}{l}22.8 \\
(2.4)\end{array}$ & $\begin{array}{l}22.1 \\
(2.6)\end{array}$ & $\begin{array}{l}0.6 \\
(-0.5 \text { to } 1.7)\end{array}$ & 0.25 & $\begin{array}{l}22.1 \\
(2)\end{array}$ & $\begin{array}{l}23.8 \\
(3.4)\end{array}$ & $\begin{array}{l}-1.7 \\
(-2.9 \text { to }-0.5)\end{array}$ & 0.006 \\
\hline Change in BMI & $\begin{array}{l}0.1 \\
(1.1)\end{array}$ & $\begin{array}{l}-0.2 \\
(1.1)\end{array}$ & $\begin{array}{l}0.3 \\
(-0.2 \text { to } 0.8)\end{array}$ & 0.22 & $\begin{array}{l}0.0 \\
(1.0)\end{array}$ & $\begin{array}{l}0.1 \\
(1.2)\end{array}$ & $\begin{array}{l}-0.1 \\
(-0.7 \text { to } 0.5)\end{array}$ & 0.7 \\
\hline Baseline QCT $\left(\mathrm{mg} / \mathrm{cm}^{3}\right)$ & $\begin{array}{l}152.9 \\
(21.6)\end{array}$ & $\begin{array}{l}148.6 \\
(23.3)\end{array}$ & $\begin{array}{l}4.3 \\
(-5.6 \text { to } 14.2)\end{array}$ & 0.39 & $\begin{array}{l}154.3 \\
(21.7)\end{array}$ & $\begin{array}{l}141.6 \\
(21.3)\end{array}$ & $\begin{array}{l}12.7 \\
\text { (1.8 to 23.7) }\end{array}$ & 0.02 \\
\hline Final QCT $\left(\mathrm{mg} / \mathrm{cm}^{3}\right)$ & $\begin{array}{l}150.6 \\
(21.9)\end{array}$ & $\begin{array}{l}143.3 \\
(22.5)\end{array}$ & $\begin{array}{l}7.3 \\
(-2.6 \text { to } 17.1)\end{array}$ & 0.15 & $\begin{array}{l}151.1 \\
(22)\end{array}$ & $\begin{array}{l}137.6 \\
(20.4)\end{array}$ & $\begin{array}{l}13.5 \\
\text { (2.5 to 24.5) }\end{array}$ & 0.02 \\
\hline $\mathrm{QCT}$ change $/ \mathrm{y}\left(\mathrm{mg} / \mathrm{cm}^{3}\right)$ & $\begin{array}{l}-2.2 \\
(4.4)\end{array}$ & $\begin{array}{l}-4.9 \\
(5)\end{array}$ & $\begin{array}{l}2.7 \\
(0.7 \text { to } 4.8)\end{array}$ & 0.01 & $\begin{array}{l}-3.5 \\
(5.1)\end{array}$ & $\begin{array}{l}-2.0 \\
(3.4)\end{array}$ & $\begin{array}{l}-1.5 \\
(-3.9 \text { to } 0.9)\end{array}$ & 0.56 \\
\hline Years between QCT & $\begin{array}{l}1.2 \\
(0.5)\end{array}$ & $\begin{array}{l}1.3 \\
(0.6)\end{array}$ & $\begin{array}{l}-0.1 \\
(-0.3 \text { to } 0.1)\end{array}$ & 0.45 & $\begin{array}{l}1.0 \\
(0.2)\end{array}$ & $\begin{array}{l}2.2 \\
(0.3)\end{array}$ & $\begin{array}{l}-1.2 \\
(-1.2 \text { to }-1.1)\end{array}$ & $<0.001$ \\
\hline Serum calcium (mmol/L) & $\begin{array}{l}2.27 \\
(0.11)\end{array}$ & $\begin{array}{l}2.31 \\
(0.09)\end{array}$ & $\begin{array}{l}-0.03 \\
(-0.08 \text { to } 0.01)\end{array}$ & 0.17 & $\begin{array}{l}2.28 \\
(0.11)\end{array}$ & $\begin{array}{l}2.32 \\
(0.06)\end{array}$ & $\begin{array}{l}-0.04 \\
(-0.10 \text { to } 0.01)\end{array}$ & 0.112 \\
\hline Serum phosphate (mmol/L) & $\begin{array}{l}1.15 \\
(0.10)\end{array}$ & $\begin{array}{l}1.14 \\
(0.12)\end{array}$ & $\begin{array}{l}0.02 \\
(-0.03 \text { to } 0.06)\end{array}$ & 0.48 & $\begin{array}{l}1.16 \\
(0.10)\end{array}$ & $\begin{array}{l}1.10 \\
(0.11)\end{array}$ & $\begin{array}{l}0.06 \\
(0.00 \text { to } 0.11)\end{array}$ & 0.035 \\
\hline Osteocalcin (ng/ml) & $\begin{array}{l}4.18 \\
(1.19)\end{array}$ & $\begin{array}{l}4.40 \\
(1.21)\end{array}$ & $\begin{array}{l}-0.22 \\
(-0.76 \text { to } 0.31)\end{array}$ & 0.41 & $\begin{array}{l}3.99 \\
(1.14)\end{array}$ & $\begin{array}{l}5.12 \\
(0.96)\end{array}$ & $\begin{array}{l}-1.13 \\
(-1.69 \text { to }-0.57)\end{array}$ & $<0.001$ \\
\hline Estradiol (pmol/L) & $\begin{array}{l}308.1 \\
(138.9)\end{array}$ & $\begin{array}{l}284.1 \\
(137.9)\end{array}$ & $\begin{array}{l}24.0 \\
(-38.3 \text { to } 86.3)\end{array}$ & 0.45 & $\begin{array}{l}278.84 \\
(113.61)\end{array}$ & $\begin{array}{l}364.40 \\
(186.38)\end{array}$ & $\begin{array}{l}-85.57 \\
(-153.87 \text { to }-17.26)\end{array}$ & 0.015 \\
\hline
\end{tabular}




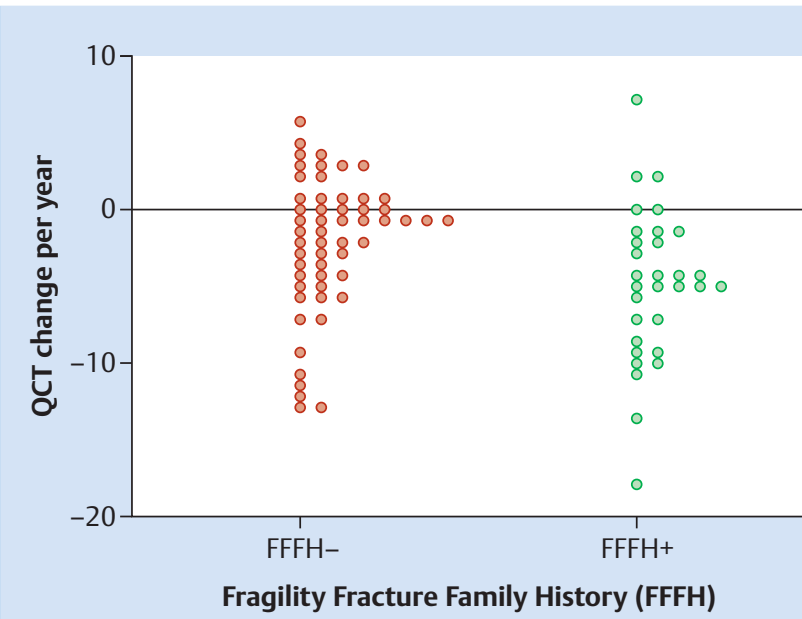

Fig. 2 Annual change in volumetric trabecular spinal bone mineral density by quantitative computed tomography (QCT) in $\mathrm{mg} / \mathrm{cm}^{3} /$ year in a cohort of 86 premenopausal women from Vancouver, Canada and Munich, Germany depicted for those without a history of a fragility fracture in a relative ( $\mathrm{FFFH}-$ ) or a positive history of fragility fractures in a family member $(\mathrm{FFFH}+$ ).

per year $\left(-4.9 \mathrm{mg} / \mathrm{cm}^{3}\right)$ than did those without FFFH $(n=55$; $-2.2 \mathrm{mg} / \mathrm{cm}^{3} ; 95 \% \mathrm{CI}$ of the difference: $-0.7,-4.8$ ). A 2-factor ANOVA of annual QCT change by center and FFFH showed that center was not significant $\left(\mathrm{F}_{1,83}=2.41, \mathrm{p}=0.12\right)$ but that a fragility fracture family history was significantly related to the rate of QCT change $\left(\mathrm{F}_{1,83}=7.88, \mathrm{p}=0.006\right)$.

A scatter-plot of individual data in the combined cohorts by the absence or presence of FFFH is shown in 0 Fig. 2. This illustrates the greater rate of loss in those who have a biological relative with a fragility fracture. Fragility fracture family history explained $7.7 \%$ of the variance in QCT change $(r=0.27)$.

\section{Discussion}

$\nabla$

This prospective study in 86 healthy, menstruating Caucasian women shows that women with a fragility fracture family history, compared to those without - lacking any other demographic, historical, nutritional, menstrual cycle, luteal phase length, exercise, hormonal or bone marker differences - have a significantly greater rate of volumetric trabecular spinal bone loss by QCT. To our knowledge this is the first time a family fragility fracture history has been shown to relate to trabecular bone loss.

It was possible to show that the simple history of a relative with a fragility fracture is associated with the rate of bone change because we studied premenopausal women in whom genetic influences on bone are more important than in older women (whose BMD may be more influenced by lifestyle factors) [31], and because our measure of bone change assessed the most sensitive bone compartment (spinal trabecular bone) using precise QCT methodology [22]. We were able to combine prospective data from two healthy cohorts of menstruating primarily white women because, although residing on different continents and studied a decade apart, they were all similarly queried about a fragility fracture in a family member, were examined using similar QCT methodology and did not differ in annualized QCT change.
In both cohorts, the history of osteoporosis in a relative is based on fragility fracture, not on a low BMD. In addition, the Munich cohort measurements provided contemporary, sensitive bone marker assays [32].

The strength of this study is that in both cohorts a wide range of variables related to baseline QCT and QCT change were measured and were not different between those with and without a family history of fragility fracture. We have shown that, by whether or not they had FFFH+, women in the combined cohort did not differ in age, BMI, exercise, menstrual cycle length (and ovulation and luteal phase length in Vancouver). Those with FFFH+ versus FFFH- also did not differ in changes in weight, exercise or other variables that were comprehensively recorded. However, the more sensitive and specific bone marker data from Munich showed higher bone resorption marker levels (NTX and CTX) in those with FFFH+. In the Vancouver cohort, lower total alkaline phosphatase levels occurred in the women with a family member who had a fragility fracture. Also, in the Vancouver cohort for whom a mean of 10 cycles per year of continuous data on luteal phase length were available, mean luteal phase length and FFFH did not significantly interact $\left(F_{2,59}=0.5029\right)$.

This study of longitudinal bone change in premenopausal women and family history of fragility fracture needs to be replicated. Such a study should optimally be performed within a populationbased multicenter study of the premenopausal population with change in BMD measures documented over $\geq$ five years. Ideally, in such a study luteal phase length would also be documented because of its importance to the rate of change in premenopausal bone density by QCT (22) as well as by DXA [34,35]. A theoretical study of this design could do genetic analysis of potential bonerelated polymorphisms along with a comprehensive reproductive and lifestyle history to better understand the bone loss occurring over women's average of 30-45 years of premenopausal menstruating life.

A family history of fragility fracture may add clinical information if a premenopausal woman experienced a low peak bone mass related to a late menarche or anorexia [36], or is losing BMD more rapidly than normal related to oligomenorrhea [37] or recurrent ovulatory disturbances $[22,32,33]$. Such a history likely adds to her individual fracture risk [1] and suggests that she may be losing bone more rapidly.

In summary, these prospective data by QCT of volumetric trabecular spinal BMD change show that a simple history of a fragility fracture in a biological relative predicts a greater rate of premenopausal trabecular bone loss. Preliminary bone marker data suggest that increased bone resorption, as might be hypothesized, mediates this inherited increased rate of premenopausal bone loss. To our knowledge this is the first human evidence that genetic risks for osteoporosis relate to premenopausal bone change as well as to cross-sectional BMD values. Larger and longer studies of younger men and women of white and non-white races, ideally from a population-based cohort, in whom detailed family fracture information has been collected, will likely advance our clinical understanding of the role of heredity in rates of bone loss and thus in risk for osteoporotic fractures. Also, new diagnostic techniques such as bone microstructural assessments might validate this new risk factor for bone loss as has been done for other previously under-recognized risk factors such as ankle fracture [38].

The implications of this study are that a family history of a fragility fracture in a younger, premenopausal woman who herself has osteoporosis risk factors (e.g. late menarche, previous childhood 
fractures, irregular cycles, oligo-amenorrhea or regular cycles with frequent ovulatory disturbances, such as can be found in infertility patients) should lead to increased awareness about that young woman's later risk for fracture. A next step would be to study specific diagnostic algorithms for these young women, before treatment options in this hitherto untreated population can be explored. The data clearly need replicating before general recommendations can be made or guidelines should change.

\section{Acknowledgements}

This joint analysis was made possible by a one-month stipend to JCP as visiting professor by the Institute of Advanced Studies (IAS) of the Technical University of Munich (TUM).

\section{Conflict of Interest}

None.

\section{Affiliations}

${ }^{1}$ Centre for Menstrual Cycle and Ovulation Research, Division of Endocrinology, University of British Columbia, Vancouver, BC, Canada 2 Dept. of Medicine, University of British Columbia, Vancouver, BC, Canada

3 Vancouver Coastal Health Research Institute, Vancouver, BC, Canada

${ }^{4}$ Frauenklinik und Poliklinik, Gynecologic Endocrinology and Interdisciplinary Osteoporosis Center (IOZ), Klinikum rechts der Isar, TUM Munich, Germany

\section{References}

1 Kanis JA, Johansson $\mathrm{H}$, Oden A et al. A family history of fracture and fracture risk: a meta-analysis. Bone 2004; 35: 1029-1037

2 Peacock M, Turner CH, Econs MJ et al. Genetics of osteoporosis. Endocr Rev 2002; 23: 303-326

3 Eisman JA. Genetics of osteoporosis. Endocr Rev 1999; 20: 788-804

4 Kanis JA, Johnell O, Oden A et al. Risk of hip fracture according to the World Health Organization criteria for osteopenia and osteoporosis. Bone 2000; 27: 585-590

5 Lentle B, Cheung AM, Hanley DA et al.; Scientific Advisory Council of Osteoporosis Canada. Osteoporosis Canada 2010 guidelines for the assessment of fracture risk. Can Assoc Radiol J 2011; 62: 243-250

6 Kanis JA, Oden A, Johnell O et al. The use of clinical risk factors enhances the performance of BMD in the prediction of hip and osteoporotic fractures in men and women. Osteoporos Int 2007; 18: 1033-1046

7 Seeman E, Hopper JL, Bach LA et al. Reduced bone mass in daughters of women with osteoporosis. N Engl J Med 1989; 320: 554-558

8 MacInnis RJ, Cassar C, Nowson CA et al. Determinants of bone density in 30- to 65-year-old women: a co-twin study. J Bone Miner Res 2003; 18: $1650-1656$

9 Abrahamsen B, Hjelmborg JV, Kostenuik P et al. Circulating amounts of osteoprotegerin and RANK ligand: genetic influence and relationship with BMD assessed in female twins. Bone 2005; 36: 727-735

10 Karasik D, Myers RH, Cupples LA et al. Genome screen for quantitative trait loci contributing to normal variation in bone mineral density: the Framingham Study. J Bone Miner Res 2002; 17: 1718-1727

11 Richards JB, Rivadeneira F, Inouye $M$ et al. Bone mineral density, osteoporosis, and osteoporotic fractures: a genome-wide association study. Lancet 2008; 371: 1505-1512

12 Ichikawa S, Koller DL, Padgett LR et al. Replication of previous genomewide association studies of bone mineral density in premenopausal American women. J Bone Miner Res 2010; 25: 1821-1829

13 Buie HR, Moore CP, Boyd SK. Postpubertal architectural developmental patterns differ between the L3 vertebra and proximal tibia in three inbred strains of mice. J Bone Miner Res 2008; 23: 2048-2059

14 Bouxsein ML, Myers KS, Shultz KL et al. Ovariectomy-induced bone loss varies among inbred strains of mice. J Bone Miner Res 2005; 20: 10851092
15 Garnero P, Arden NK, Griffiths G et al. Genetic influence on bone turnover in postmenopausal twins. J Clin Endocrinol Metab 1996; 81: 140146

16 Melton LJ 3rd, Khosla S, Atkinson EJ et al. Relationship of bone turnover to bone density and fractures. J Bone Miner Res 1997; 12: 1083-1091

17 Berger C, Langsetmo L, Joseph L et al.; CaMos Research Group. Association between change in BMD and fragility fracture in women and men. J Bone Miner Res 2009; 24: 361-370

18 Christian JC, Yu PL, Slemenda CW et al. Heritability of bone mass: a longitudinal study in aging male twins. Am J Hum Genet 1989; 44: 429433

19 Kelly PJ, Nguyen T, Hopper $J$ et al. Changes in axial bone density with age: a twin study. J Bone Mineral Res 1993; 8: 11-17

20 Bainbridge KE, Sowers $M$, Lin X et al. Risk factors for low bone mineral density and the 6-year rate of bone loss among premenopausal and perimenopausal women. Osteoporos Int 2004; 15: 439-446

21 Brot $C$, Jensen $L B$, Sørensen $\mathrm{OH}$. Bone mass and risk factors for bone loss in perimenopausal Danish women. J Intern Med 1997; 242: 505-511

22 Prior JC, Vigna YM, Schechter MT et al. Spinal bone loss and ovulatory disturbances. N Engl J Med 1990; 323: 1221-1227

23 Prior JC, Vigna YM, Schulzer $M$ et al. Determination of luteal phase length by quantitative basal temperature methods: validation against the midcycle LH peak. Clin Invest Med 1990; 13: 123-131

24 Bedford JL, Prior JC, Hitchcock CL et al. Detecting evidence of luteal activity by least-squares quantitative basal temperature analysis against urinary progesterone metabolites and the effect of wake-time variability. Eur J Obstet Gynecol Reprod Biol 2009; 146: 76-80

25 Prior JC, Vigna YM, Barr SI et al. Ovulatory premenopausal women lose cancellous spinal bone: a five year prospective study. Bone 1996; 18: 261-267

26 Seifert-Klauss V, Mueller JE, Luppa P et al. Bone metabolism during the perimenopausal transition: a prospective study. Maturitas 2002; 41: 23-33

27 Seifert-Klauss V, Link T, Heumann C et al. Influence of pattern of menopausal transition on the amount of trabecular bone loss. Results from a 6-year prospective longitudinal study. Maturitas 2006; 55: 317-324

28 Cann CE, Genant HK, Ettinger B et al. Spinal mineral loss in oophorectomized women. Determination by quantitative computed tomography. JAMA 1980; 244: 2056-2059

29 Kalender WA, Felsenberg D, Genant HK et al. The European Spine Phantom-a tool for standardization and quality control in spinal bone mineral measurements by DXA and QCT. Eur J Radiol 1995; 20: 83-92

30 Kalender WA, Felsenberg D, Louis $O$ et al. Reference values for trabecular and cortical vertebral bone density in single and dual-energy quantitative computed tomography. Eur J Radiol 1989; 9: 75-80

31 Rosenbrock H, Seifert-Klauss V, Kaspar S et al. Changes of biochemical bone markers during the menopausal transition. Clin Chem Lab Med 2002; 40: 143-151

32 Moayyeri A, Hammond CJ, Hart DJ et al. The UK Adult Twin Registry (TwinsUK Resource). Twin Res Hum Genet 2013; 16: 144-149

33 Waugh EJ, Polivy J, Ridout R et al. A prospective investigation of the relations among cognitive dietary restraint, subclinical ovulatory disturbances, physical activity, and bone mass in healthy young women. Am J Clin Nutr 2007; 86: 1791-1801

34 Bedford JL, Prior JC, Barr SI. A prospective exploration of cognitive dietary restraint, subclinical ovulatory disturbances, cortisol and change in bone density over two years in healthy young women. J Clin Endocrinol Metab 2010; 95: 3291-3299

35 Li D, Hitchcock CL, Barr SI et al. Negative spinal bone mineral density changes and subclinical ovulatory disturbances-prospective data in healthy premenopausal women with regular menstrual cycles. Epidemiol Rev 2014; 36: 137-147

36 Barr SI, Prior JC. The menstrual Cycle: Effects on Bone in premenopausal Women. In: Draper HH, ed. Advances in Nutritional Research, Nutrition and Osteoporosis. New York: Plenum Press; 1993

37 Popat VB, Calis KA, Vanderhoof VH et al. Bone mineral density in estrogen-deficient young women. J Clin Endocrinol Metab 2009; 94: 22772283

38 Biver E, Durosier C, Chevalley T et al. Prior ankle fractures in postmenopausal women are associated with low areal bone mineral density and bone microstructure alterations. Osteoporos Int 2015; 26: 2147-2155 